\title{
Carrier frequencies for thrombophilia-related genetic variants in a Romanian cohort
}

\author{
SIMONA TOPOLEANU ${ }^{1,2}$, CRISTINA MAMBET ${ }^{5}$, LUMINITA MARUTESCU ${ }^{1,3}$, FLORENTINA \\ IVAN $^{2}$, IRINA ALINA CUCU ${ }^{1,3}$, ANTOANELA CURICI $^{2,4}$, ILEANA STOICA $^{1}$ \\ ${ }^{1}$ University of Bucharest, Faculty of Biology, Dept. of Microbiology \& Immunology Aleea \\ Portocalelor 1-3, Sect. 6, Bucharest 060101, Romania \\ ${ }^{2}$ Synevo România, Medicover, Bucharest, Romania \\ ${ }^{3}$ Research Institute of the University of Bucharest, Earth, Environmental and Life Sciences \\ Section-ICUB, Bucharest, Romania \\ ${ }^{4}$ University of Medicine and Pharmacy "Carol Davila", Bucharest, România \\ ${ }^{5}$ Stefan S. Nicolau Institute of Virology, Bucharest, România
}

\begin{abstract}
Genetic testing for hereditary thrombophilia, an inherited predisposition to thrombotic events, is increasingly available. To evaluate the rate of positive thrombophilia tests in our laboratory we analyzed the carrier status for common thrombophilia-related gene variants in a consecutive unselected cohort of 360 Romanian patients. Genetic tests were performed on a Real-Time PCR platform. Majority of patients (98.6\%) carried at least one thrombophilic variant. The carrier frequencies for classical prothrombotic mutations in $F 5$ (Factor V Leiden) and $F 2$ genes (prothrombin G20210A mutation) were $11.67 \%$ (10.27\% heterozygous, $1.4 \%$ homozygous) and $6.95 \%$ (6.39\% heterozygous, $0.56 \%$ homozygous), respectively. Concurrently, high carrier frequencies for MTHFR c.677C $>\mathrm{T}$, MTHFR c.1298A $>\mathrm{C}$, and PAI-1 $4 \mathrm{G} / 5 \mathrm{G}$ variants, that are controversially associated with thrombophilia, were observed: $65.28 \%$ (52.5\% heterozygous, $12.78 \%$ homozygous), $53.61 \%$ ( $45 \%$ heterozygous, $8.61 \%$ homozygous), and $78.61 \%$ (49.44\% heterozygous, $29.17 \%$ homozygous), respectively. The impact of MTHFR genotypes on plasma homocysteine levels was also determined. Male carriers of TT homozygous genotype and CT heterozygous genotype of MTHFR C677T polymorphism had significantly higher levels of plasma homocysteine unrelated to age, compared to those harboring $\mathrm{CC}$ homozygous genotype $(P=0.028)$. In unselected patients a high rate of positive thrombophilia tests was observed and the clinical implications of such results need to be carefully examined.
\end{abstract}

Keywords Thrombophilia, factor V Leiden, prothrombin G20210A mutation, MTHFR polymorphisms, PAI-1 4G/5G polymorphism, plasma homocysteine level, carrier status.

To cite this article: TOPOLEANU S, MAMBET C, MARUTESCU L, IVAN F, CUCU IA, CURICI A, STOICA I. Carrier frequencies for thrombophilia-related genetic variants in a Romanian cohort. Rom Biotechnol Lett. 2021; 26(1): 2275-2282. DOI: 10.25083/rbl/26.1/2275.2282 


\section{Introduction}

Thrombophilia, commonly described as hypercoagulability, includes inherited or acquired conditions that predispose individuals to thrombotic events (STEVENS S.M et al, 2016). As opposed to antiphospholipid syndrome - the most common acquired thrombophilia - hereditary thrombophilia is mainly associated with venous thromboembolism (VTE), while the occurrence of arterial thrombosis and pregnancy complications in association with genetic thrombophilic defects is subject to many controversies and intensely investigated (MIDDELDORP, 2016). On the other hand, VTE has a complex multifactorial etiology, and a thrombophilia defect represents only one of the many risk factors. Other acquired transient or persistent conditions, such as pregnancy and puerperium, major orthopedic surgery, active cancer, use of estrogencontaining medication, obesity, prolonged immobilization, long flights, interact with genetic predisposing factors to further increase the thrombotic risk (MIDDELDORP, 2016; HEIT, 2015; BECKMAN et al, 2010).

When evaluate patients after an episode of VTE, hereditary thrombophilia is usually suspected in the following cases: young patients ( $<50$ years) with VTE, either unprovoked or associated with minor provoking factors (such as oral contraceptives), recurrent VTE especially occurring at a young age, positive family history for VTE, and VTE developed in unusual anatomic sites, such as cerebral or splanchnic veins (HEIT, 2015; BECKMAN et al, 2010; PREVITALI et al, 2011; CONNORS, 2016).

Hereditary thrombophilias that are largely recognized as strong independent risk factors for VTE development include the rare inherited deficiencies of natural anticoagulants protein $\mathrm{C}$, protein $\mathrm{S}$, and antithrombin, caused by loss-of-function mutations, and the more common gainof-function prothrombotic mutations in $F 5$ and $F 2$ genes (factor V Leiden - FVL - and prothrombin G20210A mutation) (CONNORS, 2016; ZÖLLER, 2019; MANNUCCI and FRANCHINI, 2015). Compared to heterozygotes for FVL and prothrombin 20210A carriers of endogenous anticoagulant deficiencies, homozygous defects and multiple thrombophilic abnormalities display a higher risk of VTE (MARTINELLI et al, 2014).

Also, there are genetic factors whose involvement in VTE is controversial, because they have not been conclusively associated with the risk of VTE, such as C677T and A1298C polymorphisms of methylenetetrahydrofolate reductase (MTHFR) gene or $4 \mathrm{G} / 5 \mathrm{G}$ polymorphism in the promoter of the plasminogen activator inhibitor-1 (PAI-1) (MIDDELDORP, 2016). As MTHFR encodes for an enzyme that plays a key role in the homocysteine (Hcy) metabolism, MTHFR polymorphisms, especially C677T, cause a reduction in the enzyme activity that may lead to hyperhomocysteinemia, a condition associated with an augmented risk of thrombosis (TSAI et al, 2003; ELDIBANY and CAPRINI, 2007).

Genetic testing for hereditary thrombophilia is increasingly available due to technological progress and automation. Despite a lack in published validated testing guidelines screening for heritable hypercoagulable conditions is frequently requested in various clinical settings (MORAN and BAUER, 2020).

The purpose of this paper was to evaluate the rate of positive thrombophilia tests by analyzing the carrier status for a panel of common thrombophilia-related gene variants in a consecutive unselected cohort of Romanian patients referred to a private outpatient laboratory. In addition, the impact of MTHFR genotypes, age and gender on plasma Hcy levels was assessed. Screening for inherited natural anticoagulant deficiencies usually performed by coagulometric assays was not subject of our study.

\section{Materials and Methods}

\section{Patients and samples}

We performed a retrospective analysis on a consecutive unselected cohort of Romanian patients that were referred during a three-month period (January-March 2018) to Synevo Central Laboratory for a comprehensive hereditary thrombophilia screening. Medical reasons for ordering the laboratory tests were only partly available and included the evaluation of underlying causes for a thrombotic event, pregnancy losses and other obstetrical complications, female infertility, general screening before conception or during pregnancy.

For each patient whole blood samples were collected in two ethylenediaminetetraacetic acid (EDTA) vacutainer tubes. One tube was used for genomic DNA extraction and the other one was centrifuged within 30 minutes of draw to separate plasma for homocysteine testing.

\section{Genotyping for thrombophilic variants by Real- Time PCR}

Genomic DNA was isolated from $200 \mu$ l peripheral whole blood using MagNA Pure LC DNA Isolation kit and MagNA Pure LC Instrument based on magnetic-bead technology, following the manufacturer's instructions. The DNA samples were further analyzed by Real-Time polymerase chain reaction (PCR) employing the following commercial kits (Roche Diagnostics): Factor V Leiden, Factor II G20210A Roche Diagnostics), MTHFR C677T LightMix, MTHFR A1298C LightMix and PAI-1 LightMix kits, on a LightCycler 480 II instrument (Roche Diagnostics). The genotyping assays involve Fluorescence Resonance Energy Transfer (FRET)-based hybridization probes and postamplification melting curve analysis 
allowing discrimination between three genotypes, i.e. homozygous wild type, homozygous mutant or heterozygous.

\section{Quantitative determination of plasma homocys- teine levels}

Plasma total homocysteine levels were measured by an enzymatic automated method on Roche Cobas 8000 Modular Analyzer Series. The assay displays high specificity as it shows no interference from cystathionine, an intermediate in the homocysteine metabolism.

\section{Statistical analysis}

Statistical analysis was performed with GraphPad Prism 6.01 for Windows. Gender-specific differences in the frequencies of the analyzed genetic variants were assessed by Fisher's exact test. Also, Mann-Whitney U test was used to compare plasma Hcy levels in both genders and among carriers of various MTHFR genotypes. Correlation between plasma homocysteine levels and age in male patients was evaluated using the nonparametric Spearman rank correlation coefficient. $P$ values $<0.05$ were considered statistically significant.

\section{Results}

\section{Patient characteristics}

The analyzed cohort referred for thrombophilia testing consisted of 360 patients, 260 females (72.3\%) and 100 males (27.7\%), with a median age of 34 and 44 , respectively. A significantly higher number of male patients were over the age of 40 compared to female patients (Table 1).

Table 1. Distribution of patients by gender and age group

\begin{tabular}{|c|c|c|c|}
\hline Age group & $\begin{array}{c}\text { Males } \\
(\mathbf{n = 1 0 0})\end{array}$ & $\begin{array}{c}\text { Females } \\
(\mathbf{n = 2 6 0})\end{array}$ & $\boldsymbol{P}$ value \\
\hline$<18$ years & 0 & 1 & \\
\hline $18-40$ years & 35 & 223 & \\
\hline$>40$ years & 65 & 36 & $<0.0001 * * * *$ \\
\hline
\end{tabular}

$\mathrm{P}<0.0001 * * * *$ (Fisher's exact test, male vs females)

\section{Carrier frequencies and genotype distribution of thrombophilic variants}

The carrier frequencies of well-established thrombophilic mutations in F5 (FVL) and F2 genes (prothrombin G20210A mutation) were $11.67 \%$ (10.27\% heterozygous, $1.4 \%$ homozygous) and $6.95 \%$ (6.39\% heterozygous, $0.56 \%$ homozygous), respectively. At the same time, high carrier frequencies of MTHFR c.677C $>\mathrm{T}$, MTHFR c.1298A $>\mathrm{C}$, and $P A I-14 \mathrm{G} / 5 \mathrm{G}$ variants, that are controversially associated with thrombophilia, were observed: $65.28 \%$ (52.5\% heterozygous, $12.78 \%$ homozygous), $53.61 \%$ ( $45 \%$ heterozygous, $8.61 \%$ homozygous), and $78.61 \%$ (49.44\% heterozygous, $29.17 \%$ homozygous), respectively (Figure 1).

Genotype distribution of each thrombophilic variant was assessed separately in males and females but no statistically significant gender-specific differences were found ( $\mathrm{P}>0.05$, Table 2).

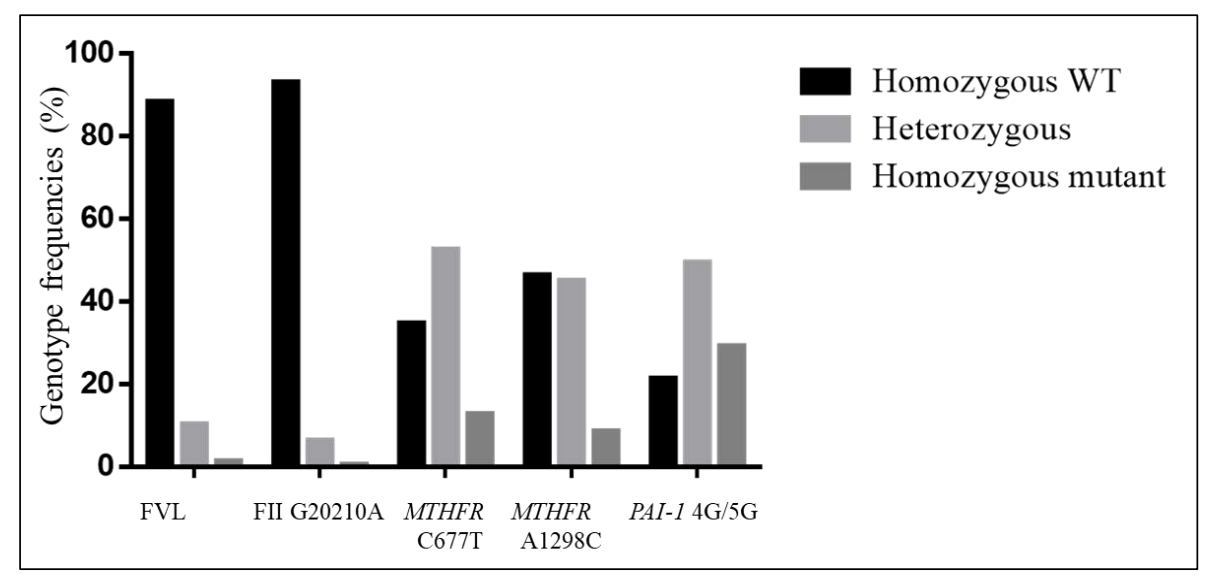

Figure 1. Genotype frequencies of thrombophilia-related variants in Romanian cohort. 
Table 2. Genotype distribution of each thrombophilic variant according to gender

\begin{tabular}{|c|c|c|c|}
\hline $\begin{array}{l}\text { Genetic variant } \\
\text { Genotypes }\end{array}$ & $\begin{array}{l}\text { Males } \\
(n=100)\end{array}$ & $\begin{array}{l}\text { Females } \\
(n=260)\end{array}$ & $P$ value \\
\hline \multicolumn{4}{|l|}{ FVL } \\
\hline Homozygous WT & $86(86 \%)$ & $232(89.23 \%)$ & 0.463 \\
\hline Heterozygous & $11(11 \%)$ & $26(10 \%)$ & 0.846 \\
\hline $\begin{array}{l}\text { Homozygous mutant } \\
\text { FII G20210A }\end{array}$ & $3(3 \%)$ & $2(0.77 \%)$ & 0.133 \\
\hline Homozygous WT & $92(92 \%)$ & $243(93.46 \%)$ & 0.645 \\
\hline Heterozygous & $7(7 \%)$ & $16(6.15 \%)$ & 0.810 \\
\hline Homozygous mutant & $1(1 \%)$ & $1(0.39 \%)$ & 0.479 \\
\hline \multicolumn{4}{|l|}{ MTHFR C677T } \\
\hline Homozygous WT & $32(32 \%)$ & $93(35.76 \%)$ & 0.538 \\
\hline Heterozygous & $54(54 \%)$ & $135(51.92 \%)$ & 0.813 \\
\hline $\begin{array}{l}\text { Homozygous mutant } \\
\text { MTHFR A1298C }\end{array}$ & $14(14 \%)$ & $32(12.32 \%)$ & 0.245 \\
\hline Homozygous WT & $40(40 \%)$ & $127(48.84 \%)$ & 0.156 \\
\hline Heterozygous & $48(48 \%)$ & $114(43.84 \%)$ & 0.480 \\
\hline Homozygous mutant & $12(12 \%)$ & $19(7.32 \%)$ & 0.206 \\
\hline \multicolumn{4}{|l|}{ PAI-1 4G/5G } \\
\hline Homozygous WT & $21(21 \%)$ & $56(21.53 \%)$ & 1.00 \\
\hline Heterozygous & $52(52 \%)$ & $126(48.47 \%)$ & 0.558 \\
\hline Homozygous mutant & $27(27 \%)$ & $78(30 \%)$ & 0.606 \\
\hline
\end{tabular}

In the entire cohort a total number of 777 genetic variants was identified, meaning that for an individual patient more than one thrombophilic defect was detected, with a maximum number of 4 genetic variants per person. Out of 360 patients, $355(98.6 \%)$ carried at least one thrombophilic gene variant and $297(82.5 \%)$ carried at least two risk variants. The compound heterozygous status for FVL and FII G20210A was identified in 3 patients (0.83\%) and the association of $\mathrm{T}$ allele of the C677T MTHFR polymorphism with FVL or FII G20210A was observed in $24(6.66 \%)$ and 17 patients $(4.72 \%)$, respectively.
Impact of gender, age and the MTHFR genotypes on plasma homocysteine levels

In relation to gender, the median level of plasma homocysteine was significantly higher in male patients than the corresponding level observed in female patients (13.9 versus $9.55 \mu \mathrm{mol} / \mathrm{L}, P<0.0001$, Man-Whitney U test).

The correlation between plasma homocysteine levels and the two MTHFR polymorphisms was analyzed for both genders (Table 3, Table 4).

Table 3. Correlation between $M T H F R$ polymorphisms and plasma homocysteine levels in males

\begin{tabular}{|c|c|c|c|}
\hline & \multicolumn{2}{|c|}{ MTHFR C677T genotype } & \multirow[t]{2}{*}{$P$ value } \\
\hline & $\mathrm{CC}(\mathrm{n}=32)$ & $\mathrm{CT}+\mathrm{TT}(\mathrm{n}=68)$ & \\
\hline \multirow[t]{3}{*}{$\begin{array}{l}\text { Plasma Hcy levels } \\
(\mu \mathrm{mol} / \mathrm{L})\end{array}$} & $13.13(7.98-21.64)$ & $14.44(8.65-34.3)$ & $0.028^{*}$ \\
\hline & \multicolumn{2}{|c|}{ MTHFR A1298C genotype } & \\
\hline & $\mathrm{AA}(\mathrm{n}=40)$ & $\mathrm{AC}+\mathrm{CC}(\mathrm{n}=60)$ & \\
\hline $\begin{array}{l}\text { Plasma Hcy levels } \\
(\mu \mathrm{mol} / \mathrm{L})\end{array}$ & $14.11(8.65-26.11)$ & $13.45(7.98-25.97)$ & 0.415 \\
\hline
\end{tabular}


Table 4. Correlation between MTHFR polymorphisms and plasma homocysteine levels in females

\begin{tabular}{|c|c|c|c|}
\hline & \multicolumn{2}{|c|}{ MTHFR C677T genotype } & $P$ value \\
\hline & $\mathrm{CC}(\mathrm{n}=93)$ & $\mathrm{CT}+\mathrm{TT}(\mathrm{n}=167)$ & \\
\hline \multirow{3}{*}{$\begin{array}{l}\text { Plasma Hcy levels } \\
(\mu \mathrm{mol} / \mathrm{L})\end{array}$} & $9.0(3.8-24.9)$ & $9.7(3.46-24.46)$ & 0.921 \\
\hline & \multicolumn{2}{|c|}{ MTHFR A1298C genotype } & \\
\hline & $\mathrm{AA}(\mathrm{n}=127)$ & $\mathrm{AC}+\mathrm{CC}(\mathrm{n}=133)$ & \\
\hline $\begin{array}{l}\text { Plasma Hcy levels } \\
(\mu \mathrm{mol} / \mathrm{L})\end{array}$ & $9.6(4.4-23.9)$ & $9.3(3.46-24.9)$ & 0.456 \\
\hline \multicolumn{4}{|c|}{$\begin{array}{l}\text { Values for plasma homocysteine are expressed as median (range). } \\
\text { P value based on Mann-Whitney U test (heterozygous and homozygous genotypes of } \\
\text { thrombophilia-related MTHFR variant vs homozygous wild-type MTHFR genotype) } \\
\text { Hcy, homocysteine }\end{array}$} \\
\hline
\end{tabular}

Male carriers of TT homozygous genotype and CT heterozygous genotype of MTHFR C677T polymorphism had significantly higher levels of plasma homocysteine that were not correlated with age (Figure 2), compared to those harboring $\mathrm{CC}$ homozygous genotype $(P=0.028)$. On the other hand, this association was not found in the female group $(P=0.921)$.
In both men and women, there was no significant difference in plasma homocysteine levels in carriers of $\mathrm{CC}$ homozygous and $\mathrm{AC}$ heterozygous genotype of MTHFR A1298C polymorphism compared to carriers of AA wildtype genotypes $(P=0.415, P=0.456)$.

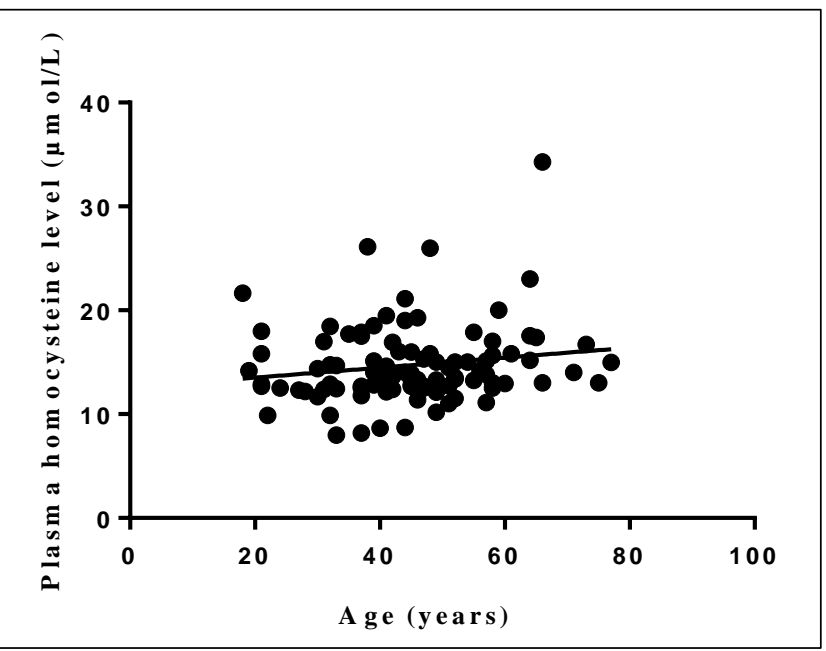

Figure 2. Correlation between plasma homocysteine levels and age in male patients (Spearman correlation coefficient $r=0.164, P=0.102$ ).

The highest homocysteine level in the male group (34.3 $\mu \mathrm{mol} / \mathrm{L})$ was identified in 66 year-old patient homozygous for MTHFR C677T that carried also heterozygous FVL and PAI-1 4G variant.

\section{Discussion}

In our cohort of patients tested for an extended panel of thrombophilia genetic variants, including both classical prothrombotic mutations and common polymorphisms having a controversial contribution to the hypercoagulable state, a high rate of positive result was observed.

As FVL and prothrombin (FII) G20210A mutation represent the most frequent heritable factors associated with thrombosis (FAVALORO, 2019) they should be considered first-line tests when screening for thrombophilia would provide useful information for the management of patients. FVL causes an increased resistance to activated protein $\mathrm{C}$ facilitating an increased thrombin generation, while prothrombin G20210A mutation is associated with a $30 \%$ increase in plasma levels of prothrombin, the precursor of thrombin (MORAN and BAUER, 2020; FAVALORO, 2019). The prevalence of FVL depends on races, ranging from $5.27-11 \%$ in the Caucasian population to approximately $1 \%$ in African populations (MUKESH and WEI, 2019). In unselected VTE patients FVL prevalence is approximately $20 \%$ (MANNUCCI and FRANCHINI, 2015).

Prothrombin G20210A mutation has a prevalence that ranges from $1 \%$ to $6 \%$ in general Caucasian population, and from $5 \%$ to $19 \%$ in VTE patients (AL SHEEF 
et al, 2019; CARROLL and PIAZZA, 2018). Although rare, homozygous and compound heterozygous carriers for FVL and FII G20210A exhibit a significantly increased risk of VTE recurrence (FEDERICI and AL-MONDHIRY, 2019). As shown by various studies, both FVL and FII G20210A mutation have not been consistently associated with an increased risk of arterial thrombosis. On the contrary, heterozygous carriers of either FVL or FII G20210A mutation have a two-fold increased risk of recurrent pregnancy loss (CARROLL and PIAZZA, 2018). The carrier frequencies for FVL $(11.67 \%)$ and prothrombin G20210A (6.95\%) mutation detected in our cohort are slightly higher than expected in general population but lower than those reported in VTE patients, suggesting that patient selection for thrombophilia testing was not optimal. Our observations are in agreement with the conclusions drawn from a previous study (FAVALORO, 2019).

The single-nucleotide PAI-1 4G/5G polymorphism (rs1799889) consists of a guanosine deletion/insertion in the promoter region at position -675 (ZHAO et al, 2012). Compared to the $5 \mathrm{G}$ allele, the $4 \mathrm{G}$ allele exhibits higher transcriptional activity, leading to increased PAI-1 plasma levels, and consequently to a hypofibrinolytic state. The highest PAI-1 level is encountered in carriers of $4 \mathrm{G} / 4 \mathrm{G}$ genotype and the lowest in those harboring $5 \mathrm{G} / 5 \mathrm{G}$ genotype (ZHANG et al, 2020). However, there are many controversies about the increased thrombotic risk conferred by PAI-1 4G/5G polymorphism. In a recent comprehensive meta-analysis it was found that rs1799889 was significantly associated with VTE in Caucasian as well as in East-Asian populations. In addition, similar positive findings were obtained in individuals with deep vein thrombosis and in FVL carriers (HUANG et al, 2020). As higher plasma levels of PAI-1 lead to increased fibrin formation that could impair placenta circulation and embryo implantation, $P A I-1$ polymorphism was also linked to recurrent pregnancy loss (JEDDI-TEHRANI, 2011). Thus, in a meta-analysis of 22 studies which included 4306 patients and 3076 controls it was suggested that the PAI-1 $4 \mathrm{G} / 5 \mathrm{G}$ polymorphism might be associated with recurrent miscarriages in Caucasians (LI et al, 2015). On the contrary, in a previous meta-analysis conducted by Su et al. the PAI-1 polymorphism did not pose a risk for recurrent pregnancy loss (SU et al, 2013). These conflicting data may be partly explained by the high frequency of $4 \mathrm{G}$ allele in worldwide population, that also registers variations among different ethnical groups, that makes the correlation of rs1799889 with the risk of pregnancy loss difficult to unequivocally establish (ADLER et al, 2018). According to Centers for Disease Control and Prevention the $4 \mathrm{G}$ allele frequencies in various populations ranges from $26.7 \%$ to $52.5 \%$ (WANG et al, 2013). In a German study, the genotype distribution of the $4 \mathrm{G} / 5 \mathrm{G} P A I-1$ polymorphism in healthy population was the following: 4G/4G $29.4 \%$, 4G/5G 48.2\%, 5G/5G 22.4\% (HOPPE et al, 2006). Similarly, in Czech Republic it was reported a frequency of $30.26 \%$ for $4 \mathrm{G} / 4 \mathrm{G}$ homozygous genotype, $50.56 \%$ for $4 \mathrm{G} / 5 \mathrm{G}$ heterozygous genotype and $19.19 \%$ for $5 \mathrm{G} / 5 \mathrm{G}$ homozygous genotype (KVASNIČKA et al, 2014). In our study, the distribution of PAI-1 genotypes in the unselected cohort resembles the distribution described in general population for the above-mentioned European countries, raising a question about the clinical relevance of PAI-I polymorphism genotyping in the analyzed group.

MTHFR is a crucial enzyme for homocysteine and folate metabolism. Its activity is related to the reduction of 5,10 methylenetetrahydrofolate to 5,10 methyltetrahydrofolate, the latter providing the methyl group necessary for the conversion of homocysteine to methionine. In case of a reduced MTHFR activity hyperhomocysteinemia may occur, especially if folate levels are insufficient (LONG and GOLDBLATT, 2016). Hyperhomocysteinemia is, in turn, largely regarded as a risk factor for cardiovascular and neurological disorders (e.g. coronary artery disease, venous and arterial thrombosis, stroke) as well as for pregnancy complications and fetal neural tube defects (TINELLI et al, 2019). The interest in the common C677T and A1298C MTHFR polymorphisms comes from their association with various degree of enzyme activity impairment. The TT genotype of C677T polymorphism has the most severe effect, leading to approximately $70 \%$ loss of enzyme function, followed by CT genotype that results in up to $35 \%$ decrease of MTHFR enzymatic activity (KURZAWSKI et al, 2015). As opposed to C677T, the A1298C polymorphism causes less pronounced reductions in enzyme function and, consequently, lower plasma homocysteine levels (MOTTAGHI et al, 2019). In a recent meta-analysis of 99 genetic association studies it is concluded that C677T polymorphism may be involved in the occurrence of deep vein thrombosis and pulmonary embolism, while A1298C polymorphism may be linked to pulmonary embolism (ZENG J. and ZENG Q, 2019). Concerning the association of MTHFR polymorphisms with poor pregnancy outcome, an evaluation of 11 systematic reviews and meta-analyses emphasized a significant correlation of $\mathrm{C} 677 \mathrm{~T}$ with recurrent pregnancy loss, especially in Asian women (DU et al, 2019). However, despite its association with hyperhomocysteinemia and increased risk for VTE, and possibly with recurrent pregnancy loss, the clinical benefit of genotyping C677T polymorphism remains unclear (WHAYNE, 2015). The American College of Medical Genetics and Genomics does not recommend ordering genotyping tests for MTHFR polymorphisms in the evaluation of thrombophilia and recurrent miscarriage, suggesting that measuring plasma homocysteine levels would be more edifying (HICKEY et al, 2013). According to data from the 1000 Genomes Project about $36 \%$ of Europeans carry T allele of C677T polymorphism, the approximate frequency of the homozygous TT genotype being 13.5\% (GRAYDON et al, 2019). The corresponding frequencies of $C$ allele of A1298C polymorphism and of CC genotype in European population are $31 \%$ and $11 \%$, respectively (GRAYDON et al, 2019). In our unselected cohort, the carrier frequencies for $M T H F R$ c. $677 \mathrm{C}>\mathrm{T}$ and MTHFR c. $1298 \mathrm{~A}>\mathrm{C}$ variants (65.28\% and $53.61 \%$, respectively) are higher than those reported in general population from European countries, due to a higher frequency of heterozygous genotypes. This 
observation suggests that MTHFR polymorphisms may be encountered more frequently in patients with clinical suspicion of thrombophilia than in healthy individuals. However, as long as medical reasons for ordering genotyping tests were not available for all patients, the association of MTHFR variants with certain pathological conditions cannot be proven. The lack of clinical data represents the main limitation of our study.

When analyzing the impact of MTHFR genotypes on plasma homocysteine levels we found significantly higher levels of plasma homocysteine only in male carriers of T allele of the MTHFR C677T polymorphism. The fact that a percentage of women might have taken folic acid supplements at the moment of blood drawing could partly explain this finding. As increasing age and male gender were previously associated with elevated plasma homocysteine levels (BAKEBERG et al, 2019) we tested the correlation between plasma homocysteine levels and age in male patients and we found that the contribution of the C677T MTHFR genotypes to the levels of plasma homocysteine was independent of age.

In order to evaluate properly the individual thrombosis risk, none of the genetic and biochemical markers have to be considered alone, but in combination and including also the environmental (nutritional) aspects (FILIPESCU et al, 2015).

\section{Conclusion}

As a summary, in unselected patients referred to a private outpatient laboratory a high rate of positive thrombophilia tests was observed and the clinical implications of such results need to be carefully examined. Extended thrombophilia panels offer comprehensive information concerning the carrier status for various thrombophilia-related variants and the combined thrombotic risk, although they pose the disadvantage of including polymorphisms that are highly frequent in general population. By following evidence-based guidelines a better selection of patients might be obtained so that genotyping tests would really provide useful data for the clinical management. Measuring homocysteine plasma concentrations may be warranted in evaluation of young patients with unexplained thrombotic events.

\section{References}

1. ADLER G., MAHMUTBEGOVIC E., VALJEVAC A., ADLER M.A., MAHMUTBEGOVIC N., SAFRANOW K., CZERSKA E., PAWINSKA-MATECKA A., CIECHANOWICZ I., MARJANOVIC D. (2018). Association Between - 675 ID, 4G/5G PAI-1 Gene Polymorphism and Pregnancy Loss: A Systematic Review. Acta Inform Med., 26(3), 156-159, http://doi: 10.5455/aim.2018.26.156-159

2. AL SHEEF M., ALMOHAYA M.S., MIAN A.M., ALJUHAYYIM S.M. (2019). Homozygous prothrombin gene mutation and ischemic cerebrovascular disease: A case report and review of literature. J Appl Hematol [serial online] [cited 2020 Apr 26], 10, 70-72. Available from: http://www.jahjournal.org/text.asp?2019/10/2/70/262539
3. BAKEBERG M.C., JEFFERSON A., RILEY M., BYRNES M., GHOSH S., MASTAGLIA FL, HORNE M.K, MCGREGOR S., STELL R., KENNA J., WALTERS S., HINCE D., ANDERTON RS. (2019). Elevated Serum Homocysteine Levels Have Differential Gender-Specific Associations With Motor and Cognitive States in Parkinson's Disease. Parkinsons Dis, 29, 2019:3124295, https://doi.org/10.1155/2019/3124295

4. BECKMAN M.G., HOOPER W.C., CRITCHLEY S.E., ORTEL T.L. (2010). Venous thromboembolism: a public health concern. Am J Prev Med, 38 (4 Suppl), S495-501, https://doi.org/10.1016/j.amepre.2009.12.017

5. CARROLL B.J., PIAZZA G. (2018). Hypercoagulable States in Arterial and Venous Thrombosis: When, How, and Who to Test?. Vasc Med, 23(4), 388-399.

6. CONNORS J.M. (2017). Thrombophilia Testing and Venous Thrombosis. N Engl J Med , 377(12), 1177-1187, doi:10.1056/NEJMra1700365

7. DU B., SHI X., YIN C., FENG X. (2019). Polymorphisms of Methalenetetrahydrofolate Reductase in Recurrent Pregnancy Loss: An Overview of Systematic Reviews and Meta-Analyses. J Assist Reprod Genet, 36(7), 13151328, DOI: 10.1007/s10815-019-01473-2

8. ELDIBANY M.M., CAPRINI J.A. (2007). Hyperhomocysteinemia and thrombosis: an overview. Arch Pathol Lab Med, 131(6), 872-184, doi: 10.1043/1543-2165 (2007)131[872:HATAO]2.0.CO,2

9. FAVALORO E.J. (2019). Genetic Testing for Thrombophilia-Related Genes: Observations of Testing Patterns for Factor V Leiden (G1691A) and Prothrombin Gene "Mutation" (G20210A). Semin Thromb Hemost, 45(7), 730-742, doi: 10.1055/s-0039-1694772

10. FEDERICI E.H., AL-MONDHIRY H. (2019). High risk of thrombosis recurrence in patients with homozygous and compound heterozygous factor V R506Q (Factor V Leiden) and prothrombin G20210A. Thromb Res., 182, 75-78, https://doi.org/10.1016/j.thromres.2019.07.030

11. FILIPESCU G.A., CUCU N., ARSENE C., NEDELCU D., ONISAI M., IONESCU C., ANDREESCU N., MEHEDINTU C., SOCOLOV D., PUIU M. (2015). Genetic and Biochemical thrombosis risk markers in pregnancy. I. Coagulation pathway, Romanian Biotechnological Letters, 19(6),9940-9951.

12. GRAYDON J.S., CLAUDIO K., BAKER S., KOCHERLA M., FERREIRA M., ROCHE-LIMA A., RODRÍGUEZ-MALDONADO J., DUCONGE J., RUAÑO G. (2019). Ethnogeographic prevalence and implications of the $677 \mathrm{C}>\mathrm{T}$ and $1298 \mathrm{~A}>\mathrm{C}$ MTHFR polymorphisms in US primary care populations. Biomark Med, 13(8), 649-661, https://doi.org/10.2217/bmm-20180392

13. HEIT J.A. (2015). Epidemiology of venous thromboembolism. Nat Rev Cardiol., 12(8), 464-474, doi: 10.1038/nrcardio. 2015.83

14. HICKEY S.E., CURY S.J., TORIELLO H.V. (2013). ACMG Practice Guideline: lack of evidence for MTHFR polymorphism testing. Genet Med, 15(2), 153-156, doi:10.1038/gim.2012.165

15. HOPPE B., TOLOU F., DÖRNER T., KIESEWETTER H., SALAMA A. (2006). Gene polymorphisms implicated in influencing susceptibility to venous and arterial thromboembolism: frequency distribution in a healthy 
German population. Thromb Haemost, 96(4), 465-470, DOI: $10.1160 /$ TH06-06-0312

16. HUANG G., WANG P., LI T., DENG X. (2019). Genetic Association Between Plasminogen Activator inhibitor-1 rs1799889 Polymorphism and Venous Thromboembolism: Evidence From a Comprehensive Meta-Analysis. Clin Cardiol, 42(12), 1232-1238, https://doi.org/10.1002/ clc. 23282

17. JEDDI-TEHRANI M., TORABI R., ZARNANI A.H., MOHAMMADZADEH A., AREFI S., ZERAATI H., AKHONDI M.M., CHAMANI-TABRIZ L., IDALI F., EMAMI S., ZAREI S. (2011). Analysis of plasminogen activator inhibitor-1, integrin beta 3 , beta fibrinogen, and methylenetetrahydrofolate reductase polymorphisms in Iranian women with recurrent pregnancy loss. Am $J$ Reprod Immunol, 66(2), 149-156, https://doi.org/10.1111/ j.1600-0897.2010.00974.x

18. KURZAWSKI M., WAJDA A., MALINOWSKI D., KAZIENKO A., KURZAWA R., DROZDZIK M. (2015). Association study of folate-related enzymes (MTHFR, MTR, MTRR) genetic variants with non-obstructive male infertility in a Polish population. Genet Mol Biol, 38(1), 42-47. http://dx.doi.org/10.1590/S1415-475738120140179

19. KVASNIČKA T., HÁJKOVÁ J., BOBČÍKOVÁ P., CVERHOVÁ V., MALÍKOVÁ I., ULRYCH J., BŘÍZA J., DUŠKOVÁ D., POLETÍNOVÁ S., KIEFEROVÁ V. KVASNIČKA J. (2014). The Frequencies of Six Important Thrombophilic Mutations in a Population of the Czech Republic. Physiol Res, 63(2), 245-253.

20. LI X, LIU Y., ZHANG R., TAN J., CHEN L., LIU Y. (2015). Meta-analysis of the association between plasminogen activator inhibitor-1 $4 \mathrm{G} / 5 \mathrm{G}$ polymorphism and recurrent pregnancy loss. Med Sci Monit, 21, 10511056, DOI: 10.12659/MSM.892898

21. LONG S., GOLDBLATT J. (2016). MTHFR Genetic Testing: Controversy and Clinical Implications. Aust Fam Physician, 45(4), 237-240.

22. MANNUCCI P.M., FRANCHINI M. (2015). Classic thrombophilic gene variants. Thromb Haemost, 114(5), 885-889, doi: 10.1160/TH15-02-0141

23. MARTINELLI I., DE STEFANO V., MANNUCCI P.M. (2014). Inherited risk factors for venous thromboembolism. Nat Rev Cardiol, 11(3), 1401-1456, doi:10.1038/ nrcardio.2013.211

24. MIDDELDORP S. (2016). Inherited thrombophilia: a double-edged sword. Hematology Am Soc Hematol Educ Program, 1, 1-9, https://doi.org/10.1182/asheducation2016.1.1

25. MORAN J., BAUER K.A. (2020). Managing thromboembolic risk in patients with hereditary and acquired thrombophilias. Blood, 135(5), 344-350, https://doi.org/ 10.1182/blood.2019000917

26. MOTTAGHI T., KHORVASH F., KHEIROLLAHI M., MARACY M., ASKARI G. (2019). The MTHFR C677T Polymorphism Influences the Efficacy of Folic Acid Supplementation on the Nerve Conduction Studies in Patients With Diabetic Polyneuropathy, A Randomized, Double Blind, Placebo-Controlled Study. J Res Med Sci, 24, 36, DOI: $10.4103 /$ jrms.JRMS_774_18
27. MUKESH S., WEI L. (2019). Factor V Leiden and the Risk of Pulmonary Embolism. Cardiol Cardiovasc Med, 3 (1), 001-008, DOI: 10.26502/fccm.92920047

28. PREVITALI E., BUCCIARELLI P., PASSAMONTI S.M., MARTINELLI I. (2011). Risk factors for venous and arterial thrombosis. Blood Transfus, 9(2), 120-138, https://doi.org/10.1038/nrcardio.2015.83

29. STEVENS S.M., WOLLER S.C., BAUER K.A., KASTHURI R., CUSHMAN M., STREIFF M., LIM W., DOUKETIS J.D. (2016). Guidance for the evaluation and treatment of hereditary and acquired thrombophilia. J Thromb Thrombolysis, 41, 154-164, https://doi.org/ 10.1007/s11239-015-1316-1

30. SU M.T., LIN S.H., CHEN Y.C., KUO P.L. (2013). Genetic association studies of ACE and PAI-1 genes in women with recurrent pregnancy loss: a systematic review and meta-analysis. Thromb Haemost, 109(1), 8-15, DOI: 10.1160/TH12-08-0584

31. TINELLI C., DI PINO A., FICULLE E., MARCELLI S., FELIGIONI M. (2019). Hyperhomocysteinemia as a Risk Factor and Potential Nutraceutical Target for Certain Pathologies. Front Nutr, 6, 49, https://doi.org/10.3389/ fnut.2019.00049

32. TSAI A.W., CUSHMAN M., TSAI M.Y., HECKBERT S.R., ROSAMOND W.D., ALEKSIC N., YANEZ N.D., PSATY B.M., FOLSOM A.R. (2003). Serum homocysteine, thermolabile variant of methylene tetrahydrofolate reductase (MTHFR), and venous thromboembolism: Longitudinal Investigation of Thromboembolism Etiology (LITE). Am J Hematol, 72(3), 192-200, https://doi.org/ 10.1002/ajh.10287

33. WANG S., CAO Q., WANG X., LI B., TANG M., YUAN W., FANG J., QIAN J., QIN C., ZHANG W. (2013). PAI-1 4G/5G Polymorphism Contributes to Cancer Susceptibility: Evidence From Meta-Analysis. PLoS One, 8(2), e56797, https://doi.org/10.1371/journal.pone.0056797

34. WHAYNE T.F. Jr. (2015). Methylenetetrahydrofolate reductase C677T polymorphism, venous thrombosis, cardiovascular risk, and other effects. Angiology, 66, 401404, https://doi.org/10.1177\%2F0003319714548871

35. ZENG J., ZENG Q. (2019). Correlations Between Methylenetetrahydrofolate Reductase Gene Polymorphisms and Venous Thromboembolism: A Meta-Analysis of 99 Genetic Association Studies. Eur J Prev Cardiol, 26(2), 120-134, https://doi.org/10.1177\%2F2047487318 799467

36. ZHANG Q., JIN Y., LI X., PENG X., PENG N., SONG J., XU M. (2020). Plasminogen Activator inhibitor-1 (PAI-1) 4G/5G Promoter Polymorphisms and Risk of Venous Thromboembolism - A Meta-Analysis and Systematic Review. Vasa, 49(2), 141-146, https://doi.org/10.1024/ 0301-1526/a000839

37. ZHAO L., BRACKEN M.B., DEWAN A.T., CHEN S. (2012). Association Between the SERPINE1 (PAI-1) 4G/5G Insertion/Deletion Promoter Polymorphism (rs1799889) and Pre-Eclampsia: A Systematic Review and Meta-Analysis. Mol Hum Reprod, 19(3), 136-143, https://doi.org/10.1093/molehr/gas056

38. ZÖLLER B. (2019). Genetics of venous thromboembolism revised. Blood, 134(19), 1568-1570, https://doi.org/ 10.1182/blood.2019002597 